\title{
PERSEPSI NELAYAN TERHADAP PENGELOLAAN KAWASAN KONSERVASI LAUT KABUPATEN CIAMIS JAWA BARAT
}

\author{
Oleh : \\ Sopiyan Danapraja ${ }^{1}$, M. Fedi A. Sondita ${ }^{2}$ dan Irawan Muripto². \\ ${ }^{1}$ Mahasiswa Pascasarjna Sekolah Tinggi Perikanan Jakarta \\ ${ }^{2}$ Dosen Pascasarjana Sekolah Tinggi Perikanan Jakarta
}

\begin{abstract}
ABSTRAK
Peningkatan kesadaran dan keterlibatan masyarakat dalam pengelolaan Kawasan Konservasi Laut Kabupaten Kabupaten Ciamis ditujukan untuk meyakinkan masyarakat akan manfaat perlindungan kawasan tersebut. Karenanya peran serta masyarakat harus dilibatkan pada perencanaan, pelaksanaan, pemecahan kendala dan berbagai kemungkinan manfaat yang dapat diperoleh dari pengelolaan kawasan konservasi. Tujuan penelitian mengkaji hubungan karakteristik dengan persepsi dan partisipasi masyarakat, persepsi dan partisipasi dalam pengelolaan Kawasan Konservasi Laut (KKL) Kabupaten Ciamis. Metode penelitian adalah survei melalui analisis korelasi dan multivariat. Responden $72 \%$ di antaranya memiliki persepsi baik (setuju) terhadap pengelolaan KKLD. Persepsi yang baik ditunjukan terhadap program $(64,9 \%)$, pelaksanaan $(55,8 \%)$, pemecahan kendala $(55,7 \%)$ dan manfaat (62\%).
\end{abstract}

Kata Kunci : nelayan, persepsi, pengelolaan kawasan konservasi

\section{PENDAHULUAN}

Kabupaten Ciamis berada pada 740’20” - 741’20” Lintang Selatan dan 108²0’00” - 10840’00” Bujur Timur. Luas wilayah Kabupaten Ciamis secara keseluruhan mencapai 244.479 ha. Selatan Ciamis berbatasan langsung dengan Samudera Hindia. Panjang garis pantai Kabupaten Ciamis mencapai 91 $\mathrm{km}$, dengan laut seluas 67.340 ha.

Pemerintah Kabupaten Ciamis telah menerbitkan Peraturan Bupati Ciamis Nomor 15 Tahun 2008 tentang Pencadangan Lokasi Kawasan Konservasi Laut (KKL) Kabupaten Ciamis, sebagai langkah nyata keseriusan (komitmen) mengelola sumberdaya kelautan dan perikanan. Penerbitan peraturan tersebut merupakan implementasi dari UndangUndang No. 27 Tahun 2007 dan Undang-Undang No. 32 Tahun 2004.

Salah satu faktor kunci membangun pengelolaan kawasan konservasi adalah keterlibatan atau partisipasi masyarakat. Menurut Margono (1985) dalam Susiatik (1998), bahwa partisipasi masyarakat sangat mutlak diperlukan untuk keberhasilan pembangunan, pada umumnya dapat dikatakan bahwa tanpa partisipasi masyarakat setiap proyek pembangunan harus dinilai tidak berhasil. Bahkan secara tegas Gawel (1984) dalam White dkk. (1994) menyatakan bahwa tidak 
ada pengelolaan sumberdaya alam yang berhasil tanpa melibatkan masyarakat

\section{Tujuan}

Tujuan dari penelitian ini adalah mengetahui perspektif/ tanggapan masyarakat nelayan terhadap adanya kawasan konservasi. Secara khusus penelitian ini bertujuan untuk mengkaji

1. Tingkat persepsi masyarakat nelayan mengenai program, pelaksanaan, pemecahan kendala dan manfaat yang ditimbulkan dengan adanya Kawasan Konservasi Laut Kabupaten Ciamis.

2. Peran pemerintah dalam memberikan ruang atau peluang bagi masyarakat nelayan untuk mengelola Kawasan Konservasi Laut Kabupaten Ciamis.

\section{METODE PENELITIAN}

\section{Waktu dan Lokasi Penelitian}

Penelitian dilakukan pada bulan 3 Mei - 14 Juli 2012 di Kawasan Konservasi Laut Kabupaten Ciamis Provinsi Jawa Barat.

\section{Metode Pengambilan Data}

Metode penelitian persepsi masyarakat terhadap pengelolaan kawasan konservasi ini adalah metode survai. Metode ini dilakukan untuk mengumpulkan data tentang fakta dan gejala yang ada serta mencari keterangan secara faktual yang terjadi di lokasi penelitian. Pengumpulan data difokuskan pada kelompok-kelompok masyarakat yang berkaitan erat dengan lokal sebagai pengguna dari sumberdaya alam.

konservasi laut, yaitu kalangan nelayan dan tokoh masyarakat yang berdomisili di lokasi penelitian.

Jenis data yang akan dikumpulkan dari para responden adalah persepsi masyarakat terhadap keterkaitan mereka dengan KKL Kabupaten Ciamis dan pendapat mereka terhadap tujuan atau manfaat pendirian KKL dan proses pengelolaan KKL yang mencakup perencanaan, pelaksanaan, kendala dan manfaat yang timbulkan pengelolaan KKL, dan Peranan Pemerintah dalam memberikan kesempatan atau peluang bagi masyarakat di Kawasan Konservasi Laut untuk berpartisipasi dalam pengelolaan Kawasan Konservasi Laut.

Populasi dalam penelitian adalah Rumah Tangga Perikanan (RTP) nelayan yang melakukan operasi penangkapan di KKL Kabupaten Ciamis. Rumah Tangga Perikanan (RTP) yang melakukan operasi penangkapan di Kawasan Konservasi Laut Daerah Kabupaten Ciamis berjumlah 1.658 orang (BPS Ciamis, 2011), yang menyebar pada enam alat tangkap yang digunakan yaitu dogol, jaring insang (gillnet), jaring tiga lapis (tramell net), bagan, arad dan rawai.

Sampel (responden) ditentukan dengan teknik purposive sampling, dimana pengambilan sampel dihentikan bila jumlahnya telah memenuhi dan sampel yang diperoleh diasumsikan random. Pengambilan sampel menggunakan teknik sampling 
kebetulan (accidental sampling) adalah mengambil responden sebagai sampel berdasarkan kebetulan, yaitu siapa saja yang secara kebetulan bertemu dengan peneliti dapat digunakan sebagai sampel bila orang yang kebetulan ditemui cocok sebagai sumber data. Teknik ini biasanya dilakukan karena keterbatasan waktu, tenaga, dan dana sehingga tidak dapat mengambil sampel yang besar dan jauh (Sugiyono 2006). Keuntungan dari teknik ini adalah terletak pada ketepatan peneliti memilih sumber data sesuai dengan variabel yang diteliti (Arikunto, 2002).

Perhitungan besarnya responden (sampel) dengan menggunakan rumus Solvin (Umar, 2004), dengan tingkat kesalahan 10\%. Berdasarkan jumlah populasi dan rumus Slovin serta pertimbangan lain, maka jumlah sampel penelitian ini sebanyak 100 responden (Tabel 1).

Tabel 1. Jumlah Responden/sampel.

\begin{tabular}{|c|l|r|c|}
\hline No. & Kecamatan & RTP & $\begin{array}{c}\text { Jumlah sampel/ } \\
\text { Responden (orang) }\end{array}$ \\
\hline 1 & Dogol & 228 & 20 \\
\hline 2 & Gillnet & 638 & 25 \\
\hline 3 & Tramel net & 303 & 20 \\
\hline 4 & Bagan & 29 & 5 \\
\hline 5 & Rawai & 469 & 25 \\
\hline 6 & Arad & 27 & $\mathbf{1 0 0}$ \\
\hline
\end{tabular}

\section{Metode Analisa Data}

Analisa data penelitian guna menjawab masalah yang telah diajukan (dirumuskan), digunakan teknik analisis sebagai berikut :

a. Data persepi responden dan peran pemerintah masing-masing dianalisis secara univariat (jumlah, mean, persentase).

b. Untuk mengungkapkan gambaran, komposisi data dan hubungan antar variabel serta memberi “isyarat” adanya hubungan kausalitas antar variabel menggunakan tabulasi silang (cross tabulasi) dan untuk mengetahui hubungan kausalitas dua variabel digunakan uji chi-square Tabel Kontingensi. Tabel Kontingensi memuat data yang diperoleh dari sampel dan diatur berdasarkan baris dan kolom. Nilai- nilai data tersebut dinamakan frekuensi observasi ( $f_{0}$ ) (Subiyakto, 1994). Apabila banyak baris $=r$, banyak kolom $=\mathrm{k}$, dan besarnya sampel $n$, nilai frekuensi harapan baris ke i dan kolom ke j dapat diperoleh dengan rumus:

$$
f_{e_{i j}}=\frac{\left(\sum f_{0_{i}}\right)\left(\sum f_{0_{j}}\right)}{n}
$$

dengan derajat kebebasan :

$$
\text { d.f. }=(r-1)(k-1)
$$

$\chi^{2}$ diperoleh dengan rumus :

$$
\chi^{2}=\sum \frac{\left(f_{0}-f_{e}\right)^{2}}{f_{e}}
$$


HASIL DAN PEMBAHASAN

\section{Persepsi Nelayan Responden}

Dari 100 responden yang diwawancarai diketahui, $72 \%$ mempunyai persepsi yang baik (setuju) dan 20\% sangat baik (sangat setuju) terhadap pengelolaan KKLD Kabupaten Ciamis.

Persepsi yang baik ditunjukan responden terhadap program (64,9\%), pelaksanaan (55,8\%), pemecahan kendala $(55,7 \%)$ dan manfaat (62\%), seperti tercantum pada Tabel 2 . Tingkat persepsi responden dilihat berdasarkan alat tangkap menunjukan nelayan arad, gillnet, tramell net, rawai, dogol dan bagan berpersepsi baik terhadap pengelolaan kawasan konservasi. Persentase terbesar (80\%) adalah responden tramell net berpersepsi baik terhadap pengelolaan (Tabel 3).

Semua kelompok nelayan mempunyai persepsi baik terhadap pengelolaan KKL. Sosialisasi yang dilakukan Pemerintah dimulai dari tahap awal, yaitu perencanaan pembentukan KKL. Setelah itu sosialisai pengelolaan kawasan konservasi dipadukan dengan program lain, misalnya Pemberdayaan Ekonomi Masyarakat Pesisir (PEMP) dan Pengololaan Lingkungan Pesisir Berbasis Pemberdayaan Masyarakat (PLPBPM). Di Kabupaten Ciamis, penerapan konsep co-management dalam pengelolaan wilayah pesisir terpadu berada pada tahap yang paling rendah, yaitu dominasi Pemerintah dalam penyampaian informasi kepada masyarakat (Pomeroy dan Berkes, 1997). Dengan latar belakang karakter yang baik, masyarakat Ciamis memiliki persepsi yang baik terhadap program, pelaksanaan dan manfaat pengelolaan kawasan konservasi.

\section{Peran pemerintah}

Berdasarkan hasil kajian data dari responden terhadap peran pemerintah, $\quad 42 \% \quad$ responden memberikan jawaban kadang-kadang pemerintah memberikan peluang untuk berpartisipasi dalam pengelolaan KKLD (Gambar 1). Pemerintah dalam penyusunan program kawasan konservasi kadang-kadang melibatkan 41,5\% responden. Sedangkan dalam pelaksanaan pengelolaan KKLD 49\% responden kadang-kadang dilibatkan oleh pemerintah (Tabel 4).

Hasil crosstabulasi alat tengkap dengan peran pemerintah terlihat bahwa $60 \%$ responden arad dan dogol kadangkadang dilibatkan atau pemerintah dalam pengelolaan KKLD (Tabel 5). Pemerintah kadang-kadang melibatkan responden rawai $76 \%$ dalam perencanaan pengelolaan dan 96\% dalam pelaksanaan pengelolaan KKLD di Kabupaten Ciamis.

Persepsi nelayan sangat dipengaruhi kemauan politik dari pemerintah untuk melibatkan masyarakat dalam pembangunan. Sementara ini pemerintah baru memberikan peluang hanya pada sebagian dari nelayan (tokoh nelayan, pengurus kelompok). Kesempatan yang diberikan kepada masyarakat nelayan sering merupakan faktor pendorong tumbuhnya kemauan, dan kemauan akan sangat menentukan kemampuannya. 
Tabel 2. Persepsi Responden terhadap Program, Pelaksanaan, Pemecahan dan Manfaat KKLD.

\begin{tabular}{|c|c|c|c|c|c|c|c|}
\hline \multirow{2}{*}{ Persepsi } & \multirow{2}{*}{ No Pertanyaan } & \multicolumn{5}{|c|}{ Jawaban Responden } & \multirow{2}{*}{ Jumlah } \\
\hline & & STS & TS & KS & $\mathbf{S}$ & SS & \\
\hline \multirow{7}{*}{ Program } & 1 & 2 & 5 & 29 & 55 & 9 & 100 \\
\hline & 2 & 1 & 11 & 39 & 43 & 6 & 100 \\
\hline & 3 & 5 & 2 & 14 & 69 & 10 & 100 \\
\hline & 4 & - & 4 & 13 & 73 & 10 & 100 \\
\hline & 5 & 1 & 2 & 6 & 75 & 16 & 100 \\
\hline & 6 & 1 & 1 & 5 & 65 & 28 & 100 \\
\hline & 7 & 1 & 2 & 13 & 74 & 10 & 100 \\
\hline \multicolumn{2}{|c|}{ Jumlah } & 11 & 27 & 119 & 454 & 89 & 700 \\
\hline \multicolumn{2}{|c|}{ Persentase (\%) } & 1,6 & 3,8 & 17 & 64,9 & 12,7 & 100 \\
\hline \multirow{4}{*}{ Pelaksanaan } & 8 & - & 5 & 19 & 66 & 10 & 100 \\
\hline & 9 & 4 & 4 & 23 & 57 & 12 & 100 \\
\hline & 10 & 5 & 8 & 12 & 51 & 24 & 100 \\
\hline & 11 & 1 & 11 & 8 & 49 & 31 & 100 \\
\hline \multicolumn{2}{|c|}{ Jumlah } & 10 & 28 & 62 & 223 & 77 & 400 \\
\hline \multicolumn{2}{|c|}{ Persentase (\%) } & 2,5 & 7 & 15,5 & 55,8 & 19,2 & 100 \\
\hline \multirow{3}{*}{$\begin{array}{c}\text { Pemecahan } \\
\text { kendala }\end{array}$} & 12 & - & 8 & 31 & 57 & 4 & 100 \\
\hline & 13 & - & 3 & 35 & 56 & 6 & 100 \\
\hline & 14 & 1 & 4 & 21 & 54 & 20 & 100 \\
\hline \multicolumn{2}{|c|}{ Jumlah } & 1 & 15 & 87 & 167 & 30 & 300 \\
\hline \multicolumn{2}{|c|}{ Persentase (\%) } & 0,3 & 5 & 29 & 55,7 & 10 & 100 \\
\hline \multirow{8}{*}{ Manfaat } & 15 & - & - & 5 & 52 & 43 & 100 \\
\hline & 16 & - & 2 & 8 & 53 & 37 & 100 \\
\hline & 17 & - & 3 & 7 & 66 & 24 & 100 \\
\hline & 18 & - & 1 & 8 & 72 & 19 & 100 \\
\hline & 19 & - & 1 & 9 & 64 & 26 & 100 \\
\hline & 20 & - & 1 & 12 & 66 & 21 & 100 \\
\hline & 21 & - & - & 4 & 75 & 21 & 100 \\
\hline & 22 & - & 4 & 8 & 48 & 40 & 100 \\
\hline \multicolumn{2}{|c|}{ Jumlah } & $\mathbf{0}$ & 12 & 61 & 496 & 231 & 800 \\
\hline \multicolumn{2}{|c|}{ Persentase (\%) } & $\mathbf{0}$ & 1,5 & 7,6 & 62 & 28,9 & 100 \\
\hline
\end{tabular}

Ket: STS:Sangat tidak setuju, TS:Tidak setuju, KS:Kurang setuju, S:Setuju, SS:Sangat setuju

Tabel 3. Crosstabulasi Alat Tangkap dengan Persepsi Responden

\begin{tabular}{|c|c|c|c|c|c|c|}
\hline & \multicolumn{3}{|c|}{ Persepsi } & \multirow[t]{2}{*}{ Total } \\
\hline & & & Kurang setuju & Setuju & Sangat setuju & \\
\hline \multirow{7}{*}{$\mathrm{Al}$} & \multirow{2}{*}{ Arad } & Jumlah & 0 & 3 & 2 & \\
\hline & & $\%$ & $0.0 \%$ & $60.0 \%$ & $40.0 \%$ & $100.0 \%$ \\
\hline & \multirow{2}{*}{ Gill Net } & Jumlah & 1 & 19 & 5 & 25 \\
\hline & & $\%$ & $4.0 \%$ & $76.0 \%$ & $20.0 \%$ & $100.0 \%$ \\
\hline & \multirow{2}{*}{ Tramell } & Jumlah & 1 & 16 & 3 & 20 \\
\hline & & $\%$ & $5.0 \%$ & $80.0 \%$ & $15.0 \%$ & $100.0 \%$ \\
\hline & \multirow{2}{*}{ Rawai } & Jumlah & 2 & 17 & 6 & 25 \\
\hline & & $\%$ & $8.0 \%$ & $68.0 \%$ & $24.0 \%$ & $100.0 \%$ \\
\hline & \multirow{2}{*}{ Dogol } & Jumlah & 2 & 14 & 4 & 20 \\
\hline & & $\%$ & $10.0 \%$ & $70.0 \%$ & $20.0 \%$ & $100.0 \%$ \\
\hline & \multirow{2}{*}{ Bagan } & Jumlah & 2 & 3 & 0 & 5 \\
\hline & & $\%$ & $40.0 \%$ & $60.0 \%$ & $0.0 \%$ & $100.0 \%$ \\
\hline \multirow{2}{*}{ Tota } & & Jumlah & 8 & 72 & 20 & 100 \\
\hline & & $\%$ & $8.0 \%$ & $72.0 \%$ & $20.0 \%$ & $100.0 \%$ \\
\hline
\end{tabular}


Tabel 4. Peran Pemerintah Memberikan Peluang dalam Berpartisipasi

\begin{tabular}{|c|c|c|c|c|c|c|c|}
\hline \multirow{2}{*}{ Peran Pemerintah } & \multirow{2}{*}{ No Pertanyaan } & \multicolumn{5}{|c|}{ Jawaban Responden } & \multirow{2}{*}{ Jumlah } \\
\hline & & TP & $\mathbf{J}$ & KK & $\mathbf{S}$ & SL & \\
\hline \multirow{2}{*}{ Perencanaan } & 1 & 26 & 17 & 43 & 12 & 2 & 100 \\
\hline & 2 & 19 & 20 & 40 & 18 & 3 & 100 \\
\hline \multicolumn{2}{|c|}{ Jumlah } & 45 & 37 & 83 & 30 & 5 & 200 \\
\hline \multicolumn{2}{|c|}{ Persentase (\%) } & 22,5 & 18,5 & 41,5 & 15 & 2,5 & 100 \\
\hline \multirow{3}{*}{ Pelaksanaan } & 3 & 16 & 18 & 48 & 16 & 2 & 100 \\
\hline & 4 & 15 & 12 & 55 & 16 & 2 & 100 \\
\hline & 5 & 17 & 22 & 44 & 12 & 5 & 100 \\
\hline \multicolumn{2}{|c|}{ Jumlah } & 48 & 52 & 147 & 44 & 9 & 300 \\
\hline \multicolumn{2}{|c|}{ Persentase (\%) } & 16 & 17,3 & 49 & 14,7 & 3 & 100 \\
\hline
\end{tabular}

Ket: TP: Tidak pernah, J: Jarang, KK: Kadang-kadang, S: Sering, SL: Selalu

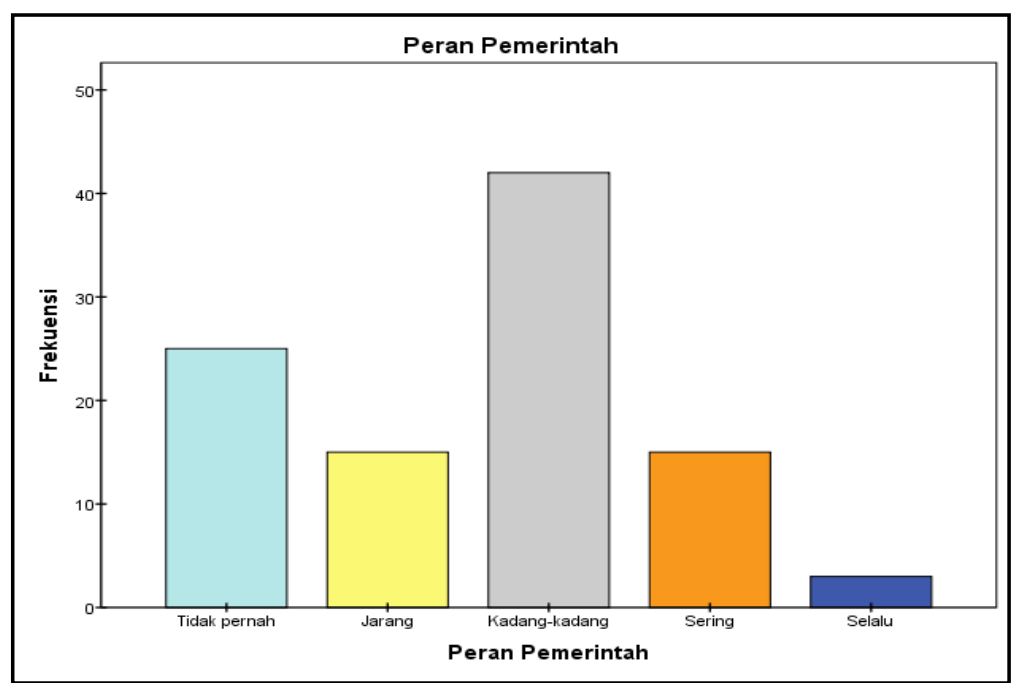

Gambar 1. Distribusi Frekuensi Peran Pemerintah

Tabel 5. Crosstabulasi Alat Tangkap dengan Peran Pemerintah

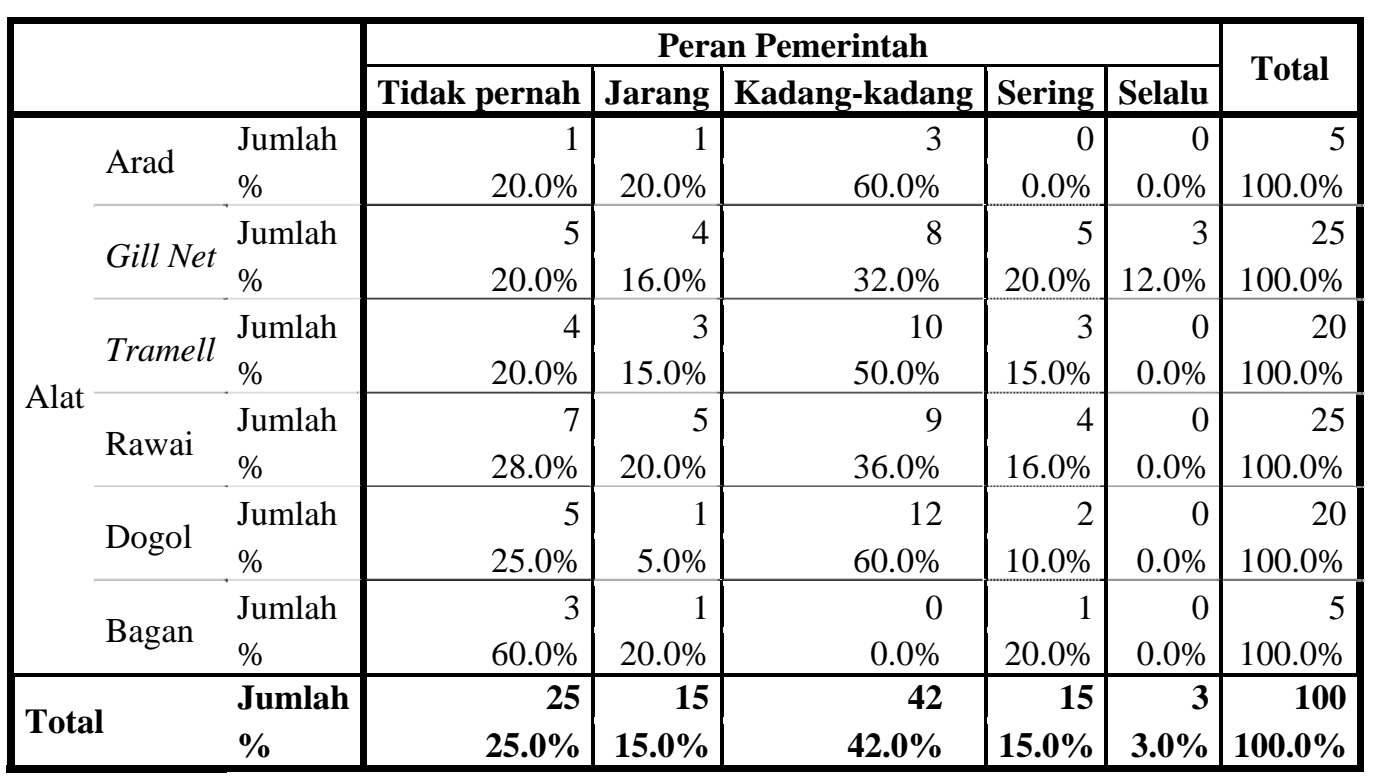




\section{KESIMPULAN}

1. Sebagian besar nelayan Ciamis memberikan kesan yang baik (setuju) pada semua indikator persepsi tentang Kawasan Konservasi Laut.

2. Pemerintah kurang berperan dalam memberikan ruang/peluang bagi masyarkat untuk berpartisipasi.

\section{DAFTAR PUSTAKA}

Arikunto, S. 2002. Prosedur Suatu Penelitian: Pendekatan Praktek. Edisi Revisi. Kelima. Rineka Cipta. Jakarta.

BPS Ciamis. 2011. Kabupaten Ciamis dalam Angka (Ciamis in Figurs) 2011. Badan Pusat Statistik. Ciamis.

Pomeroy, R. dan F. Berkes. 1997. Two to Tango : the Role of Government in Fisheries Co-Management. Marine Policy. 465-480 hal.

Susiatik, T. 1998. Persepsi dan Partisipasi Masyarakat Terhadap Kegiatan Pembangunan Masyarakat Desa Hutan Terpadu (PMDHT) di Desa Mojorebo Kecamatan Wirosari Kabupaten Dati II Grobogan Jawa Tengah. Tesis. Bogor: IPB.

Umar, H. 2004. Riset Sumberdaya Manusia. Gramedia Pustaka Utama. Jakarta. 242 hal.

White, A., L.Z. Hale, Y. Renard and L. Cortesi. 1994. Collaborative and Community Management of Coral Reefs: Lessons from Experience. Kumarian Press, Connecticut, USA. 130 hal. 